\title{
Analisis Fungsi Manajemen Organisasi Olahraga (Studi Kualitatif pada Pengurus Daerah Ikatan Sport Sepeda Indonesia Jawa Barat)
}

\author{
Alam Kautsar ${ }^{\bowtie}$, Sumardiyanto, Yati Ruhayati \\ Program Studi Ilmu keolahragaan, Departemen Pendidikan Kesehatan dan Rekreasi, Fakultas \\ Pendidikan Olahraga dan Kesehatan, Universitas Pendidikan Indonesia, Indonesia
}

\begin{tabular}{l}
\hline Info Artikel \\
\hline Sejarah Artikel: \\
Diterima: Oktober-2018 \\
Disetujui: Oktober-2018 \\
Dipublikasikan : Oktober-2018 \\
\hline Kata Kunci: \\
Manajemen, organisasi olahraga, \\
pengda ISSI
\end{tabular}

Manajemen,

\begin{abstract}
Abstrak
Penelitian ini bertujuan untuk mengetahui fungsi manajemen organisasi olahraga pada Pengurus Daerah Ikatan Sport Sepeda Indonesia Jawa Barat. Penggalian informasi diperoleh melalui pendekatan deskriptif kualitatif dengan teknik pengumpulan data wawancara terstruktur dengan alat bantu berupa pedoman wawancara, buku catatan, dan dokumentasi. Tahap pengolahan data penelitian dilakukan dengan cara reduksi data, penyajian data dan verifikasi data.

Analisis fungsi manajemen merupakan hasil dari cara pemecahan masalah melalui proses perencanaan, pengorganisasian, penggerakan, pengawasan, dan penilaian untuk memperoleh hasil yang diinginkan. Untuk menghilangkan perbedaanperbedaan konstruksi kenyataan yang ada dalam konteks suatu studi sewaktu pengumpulan data tentang berbagai kejadian dan hubungan dari berbagai pandangan, peneliti menggunakan teknik triangulasi sumber. Hasil penelitian ini menunjukan bahwa analisis fungsi manajemen organisasi olahraga Pengurus Daerah Ikatan Sport Sepeda Indonesia Jawa Barat dinilai kurang efektif.
\end{abstract}

\begin{abstract}
This study aims to determine the function of management of sports organizations in the Regional Board of Indonesian Sport Bike Association in West Java. Information gathering was obtained through a qualitative descriptive approach with structured interview data collection techniques with tools such as interview guides, notebooks, and documentation. The research data processing phase is carried out by data reduction, data presentation and data verification.

Analysis of management functions is the result of how to solve problems through the process of planning, organizing, mobilizing, monitoring, and evaluating to obtain the desired results. To eliminate the differences in the construction of reality that exists in the context of a study when collecting data on various events and relationships from various views, the researcher used source triangulation techniques. The results of this study indicate that the analysis of the management functions of the sports organization of the Regional Board of Indonesian Sport Bike Association in West Java is considered to be less effective.
\end{abstract}

(C) 2018 Universitas Pendidikan Indonesia 


\section{PENDAHULUAN}

Manajemen sangat penting bagi setiap aktivitas individu atau kelompok dalam organisasi untuk mencapai tujuan yang diinginkan. Manajemen berorientasi pada proses yang berarti bahwa manajemen membutuhkan sumber daya manusia, pengetahuan dan keterampilan agar aktivitas lebih efektif atau dapat menghasilkan tindakan dalam mencapai kesuksesan. Oleh sebab itu, tidak akan ada organisasi yang akan sukses apabila tidak menggunakan manajemen yang baik.

Ada beberapa indikasi permasalahan didalam tubuh PENGDA ISSI yang diantaranya sebagai berikut: (1) perpindahan atlet antar pengurus cabang ISSI di Jabar menjelang Pekan Olahraga Daerah (PORDA) yang banyak menuai masalah, hal ini tidak sesuai dengan fungsi pengorganisasian tentang pengelompokan orang-orang, tugas-tugas, tanggungjawab dan wewenang. (2) Aturan dalam Porda lebih memihak kepada daerah tertentu, berarti adanya penyalahgunaan wewenang. hal Ini termasuk kedalam fungsi manajemen tentang pengorganisasian tentang tugas dan tanggung jawab. (3) Tidak adanya berita acara pada setiap kegiatan yang hal ini sangat bertolak belakang dengan fungsi manajemen divisi pengawasan yang bertujuan untuk memastikan semua kegiatan yang sedang dilakukan berjalan sesuai dengan rencana yang telah ditentukan sebelumnya. (4) Pengurus daerah ikatan sepeda sport Indonesia Jawa Barat tidak ikut serta dalam kegiatan yang telah direncanakan Pengurus Besar Ikatan Sepeda Sport Indonesia dalam kejuaraan nasional ISSI 2014. Dikarenakan PENGDA ISSI JABAR mengesampingkan fungsi perencanaan dalam organisasi.

Dari indikasi-indikasi permasalahan diatas dapat menyebabkan rendahnya kualitas organisasi olahraga, seperti tidak berkembangnya atlet dan menghambat keberhasilan atau tujuan organisasi olahraga itu sendiri.

\section{METODE}

Sumber Data dan Instrumen Penelitian

Sumber data pada penelitian ini adalah pegawai dan dokumen PENGDA ISSI JABAR sebelum dibekukan. pendekatan kualitatif dengan metode deskriptif agar peneliti mendapatkan deskripsi gambaran atau lukisan secara sistematis, aktual dan akurat mengenai fakta-fakta, sifat-sifat serta hubungan antar fenomena yang akan diselidiki.

Peneliti berperan sebagai perencana, pelaksana pengumpulan data, analisis, penafsiran, dan pada akhirnya sebagai pelapor hasil penelitian. Maka dari itu peneliti tepat sekali dikatakan sebagai instumen utama dalam penelitian, karena peneliti menjadi kunci dari keseluruan penelitian. Selain itu hanya manusia yang dapat memahami makna interaksi antar manusia, membaca gerak muka, menyelami perasaan dan nilai yang terkandung dalam ucapan atau perbuatan responden. Walaupun menggunakan alat perekam atau kamera, peneliti tetap memegang peranan utama sebagai alat penelitian.

Teknik Pengumpulan Data

Pengumpulan data melalui teknik wawancara terstruktur. Wawancara adalah percakapan dengan maksud tertentu. Percakapan itu dilakukan oleh dua pihak, yaitu pewawancara (interview) yang mengajukan pertanyaan dan yang diwawancarai yang memberikan jawaban atas pertanyaan yang telah dibuat dan disusun sebelumnya.

Prosedur Penelitian

a. Persiapan Penelitian (menyusun pedoman wawancara yang kemudian dikonsultasikan kepada dosen pembimbing, lalu mengurus surat perizinan penelitian yang diperlukan).

b. Pelaksanaan Penelitian (peneliti mulai turun langsung kelapangan untuk melakukan penelitian yang sebenarnya. dimulai dengan mewawancarai para informan yang sebelumnya telah ditentukan waktu dan tempatnya. selanjutnya semua hasil wawancara ditulis kedalam catatan 
lapangan. demikian seterusnya sampai peneliti mendapatkan jawaban yang sama dari hasil wawancara dengan informan yang berbeda atau yang biasa disebut dengan titik jenuh).

c. Tahap Pengolahan Data (reduksi data, pengolahan data, dan verifikasi / kesimpulan sementara).

\section{Teknik Pengumpulan Data}

a. reduksi data merupakan rangkuman, memilih hal-hal yang pokok, memfokuskan pada hal-hal yang penting, mencari tema dan pola serta membuang hal-hal yang penting, mencari tema dan pola serta membuang hal-hal yang tidak perlu.

b. Penyajian data yaitu setelah melakukan reduksi data peneliti melakukan penyajian data hal ini bertujuan agar peneliti lebih mudah dalam mendapatkan gambaran yang lebih rinci dan menyeluruh, seingga peneliti dapat lebih mudah mendapatkan alur atau jawaban-jawaban pada fokus penelitian.

c. Verifikasi / kesimpulan sementara, yaitu upaya untuk mencari makna dari kata yang dikumpulkan, dilakukan dengan mencari pola, tema, hubungan, persamaan, hal-hal yang sering timbul dan sebagainya. Kesimpulan awal yang dikemukakan masih bersifat sementara dan akan berubah bila tidak ditemukan bukti-bukti kuat yang mendukung pada tahap pengumpulan data berikutnya.

\section{HASIL}

Dalam organisasi PENGDA ISSI terdapat 13 bidang dan komisi yang terdapat dalam struktural, peneliti akan mewawancara satu orang dari setiap komisi atau bidang yang mewakili komisi atau bidang tersebut.

Peneliti mendapatkan 7 orang responden yang bersedia memberikan informasi kepada peneliti. 6 orang responden lainnya tidak diwawancara karena data yang diperoleh oleh peneliti sudah jenuh atau data hasil wawancara hampir sama jawabannya seperti hasil wawancara responden sebelumnya.

1. Perencanaan

Dari segi perencanaan dalam analisis fungsi manajemen organisasi olahraga PENGDA ISSI JABAR dapat dikatakan bahwa perencanaan dalam organisasi PENGDA ISSI sudah dibuat, baik secara umum maupun secara khusus, terlihat dari jawaban para responden menjawab ke enam pertanyaan $5 \mathrm{w}+1 \mathrm{H}$ tentang perencanaan sesuai dengan yang tertera didalam AD/ART ISSI.

2. Pengorganisasian

Peneliti menyimpulkan bahwa orang yang menduduki suatu jabatan tidak memenuhi kualifikasi, hubungan kerja antar divisi kurang baik, keuangan; sarana dan prasarana kurang mendukung, pemberian penghargaan kepada staf berprestasi kurang memuaskan, dan kurangnya bimbingan kepada staf ketika kurang mampu menjalankan tugasnya. Hal tersebut menjadi faktor penghalang utama ke arah tercapainya tujuan yang telah ditentukan. Siagian (2015, hlm. 105) mengemukakan bahwa "pelaksanaan pengorganisasian pada hakikatnya harus bertitik tolak dari pentingnya menjadikan manusia itu sebagai unsur perangsang dan mengurangi kemungkinan timbulnya peranan manusia yang merusak organisasi".

3. Penggerakan

Penggerakan organisasi tidak cukup dengan hanya mengintruksikan kepada bawahan untuk bekerjasama dan menegur jika kurang mampu mengerjakan tugas dalam organisasi. Tetapi lebih kepada pembimbingan dalam mengerjakan tugas, karena ketika kapasitas pengetahuan bawahan atau anggotanya luas realisasi dalam pengerjaan tugasnya pun akan tercapai dengan efisien dan efektif. Hal ini dijelaskan oleh Siagian (2015, hlm. 75) dalam prinsip the ten commandments of human relations bahwa "pengembangan kemampuan bawahan sampai tingkat yang maksimal. kepada setiap orang di dalam organisasi harus diberikan kesempatan yang seluas-luasnya untuk mengembangkan kapasitas mentalnya melalui pendidikan, latihan baik 
yang bersifat latihan jabatan atau on the job training maupun yang bersifat off the job training.

\section{Pengawasan}

Setiap kegiatan yang dilaksanakan oleh PENGDA ISSI JABAR diawasi oleh KONI JABAR dan PB ISSI, fungsi pengawasan di PENGDA ISSI JABAR terlihat kurang perhatian dari ketua terhadap tugas yang dilaksanakan oleh anggota sehingga anggota yang berinisiatif melaporkan kegiatan kepada atasan baik lisan maupun tulisan. Hal ini bertolak belakang dengan yang dikemukakan Siagian (2015, hlm. 112) bahwa "pengawasan adalah proses pengamatan pelaksanaan seluruh kegiatan organisasi untuk menjamin agar semua pekerjaan yang sedang dilakukan berjalan sesuai dengan rencana yang telah ditentukan sebelumnya".

5. Evaluasi

Manajemen organisasi olahraga PENGDA ISSI JABAR peneliti berkesimpulan bahwa cara penilaian yang dilakukan oleh PENGDA ISSI JABAR yaitu dengan cara membandingkan hasil perolehan medali pada saat PON dengan perencanaan perolehan medali yang sebelumnya direncanakan. Adapun penilaian/evaluasi sudah berjalan sesuai dengan yang seharusnya yaitu pada saat MUSDA, karena penilaian atau evaluasi hanya dilakukan satu tahun sekali (pada saat MUSDA) sehingga penyelewangan atau penyimpangan tidak bisa ditindak dengan efektif dan cepat.

\section{KESIMPULAN}

Analisis fungsi manajemen organisasi olahraga PENGDA ISSI JABAR dinilai kurang efektif, hal tersebut berdasarkan dari hasil verifikasi yang disebabkan oleh orang yang menduduki jabatan dalam kepengurusan kurang memenuhi kualifikasi, tidak ada bimbingan dari pimpinan ketika anggota tidak bisa mengerjakan tugasnya, kurangnya perhatian dari pimpinan yang kemungkinan memenyebabkan pimpinan kurang mengetahui akan fakta-fakta yang ada dilapangan, dan evaluasi dilakukan pada saat MUSDA saja, hal ini menyebabkan ketika ada penyelewengan atau penyimpangan sistem tidak bisa ditindak dengan cepat dan efektif..

\section{DAFTAR PUSTAKA}

A Amirullah, dan Haris Budiyono. (2004). Pengantar Manajemen. Yogyakarta: Graha Ilmu.

Arikonto, Suharsimi. (2010). Manajemen Penelitian. Jakarta: Rineka Cipta

Bangun, Wilson. (2008). Intisari Manajemen. Bandung: PT Refika Aditama

Feriyanto, Andri, SE. \& Shyta, Endang Triana, SE. (2015). Pengantar Manajemen (3 in 1). Kebumen: Mediatera.

Gunawan, Imam, S.Pd., M.Pd., (2013). Metode Penelitian Kualitatif Teori dan Praktik. Jakarta: Bumi Aksara.

Harsuki, M.A, Prof. Dr. (2012). Pengantar Manajemen Olahraga. Jakarta: PT Rajagrafindo Persada.

Hasibuan, Malayu S. P. (2008). Manajemen dasar, Pengertian dan Masalah. Jakarta: Bumi Aksara.

Moleong, Lexy J. (2010). Metode penelitian Kualitatif. Bandung: Rosdakarya.

Nasrullah, Priadi. (2013). Manajemen Pengembangan Olahraga Rekreasi Di Dinas Pemuda, Olahraga dan Parawisata. Skripsi Sarjana pada FPOK UPI: tidak diterbitkan.

Pengda ISSI Jabar. (2015). Susunan Pengurus Pengda ISSI Jabar. Diambil pada 2 Maret 2015 dari www.pengdaissijabar.blogspot.com

Risma. (2011). Manajemen Pengembangan Taekwondo Di Kota Tasikmalaya. Skripsi Sarjana pada FPOK UPI: tidak diterbitkan.

Sarosa, Samiaji, SE, M.Sc, Ph.D. (2012). Penelitian Kualitatif Dasar-Dasar. Jakarta Barat: Indeks.

Siagian, P, Sondang, M.P.A, Prof, Dr. (2007). Manajemen Sumber Daya Manusia. Jakarta: Bumi Aksara.

Siagian, P, Sondang, M.P.A, Prof, Dr. (2015). Filsafat Administrasi. Jakarta: Bumi Aksara.

Silalahi, Ulber, M.A, Dr. (2012). Metode Penelitian Sosial. Bandung: Refika Aditama.

Subhan, Irfan "PR"/A-88. (2014). Pengda ISSI Jabar Dibekukan Sementara. Diambil pada 12 Februari 2015 dari www.pikiranrakyat.com/node/293867

Sugiyono. (2011). Metode Penelitian Kuantitatif, Kualitatif dan R \& D. Bandung: Alfabeta.

Sugiyono Prof, Dr. (2015). Metode Penelitian Kuantitatif, Kualitatif, dan R\&D. Bandung: Alfabeta. 
Alam Kautsar, Sumardiyanto, Yati Ruhayati/ Jurnal Terapan Ilmu Keolahragaan 3 (2) (2018)

Torang, Syamsir, Dr. (2014). Organisasi \& Manajemen (Perilaku, Struktur, Budaya, \& Perubahan Organisasi). Bandung: Alfabeta.

Wahidah, Ida. (2010). Manajemen Pengembangan Hoki Di Jawa Barat. Skripsi Sarjana pada FPOK UPI: tidak diterbitkan. 